\title{
COVID-19: Lessons from the Pandemic
}

\author{
Akshata Vijay Agrawa and Swarupa Chakole \\ ${ }^{1}$ Department. of Community Medicine, Jawaharlal Nehru Medical College, \\ Datta Meghe Institute of Medical Sciences, Wardha 442001 Maharashtra, India
}

\section{ABSTRACT}

COVID-19 pandemic which originated from Wuhan city of China pushed the world to face strict lockdown.Millions and Billions of people were not able to socialize, unable to meet one another, were not able to work efficiently, unable to attend school, college, gatherings, visit temples, travel and even lost access to public facilities as a result of lockdown and quarantine. Places of recreation like cinemas and shopping malls were also shut and this made the people reflect on their dependence on the external world for fulfilment. Many found it difficult to cope with it and find satisfaction without external stimuli. This also led to an increase in people signing up channels available on the internet and television. The whole world saw a setback due to the novel coronavirus and the global economy was severely affected. Many peoplelost the jobs, slept hungry, lost their homes and health.The virus impacted every sector of population. The poor and vulnerable were the worst among affected. Labourersmigrated from the cities to their villages. The worldwide economy faced a drastic downfall. The widespread change that has occurred due to the pandemic, and its effects, such as lockdown has stressed the importance of flexibility in life, immunity, digital revolution, personal hygiene and safety. This article tries to compile the key learnings taught to the mankind through this pandemic.

KEY WORDS: COVID-19, LEARNINGS, LESSONS, PANDEMIC, SANITATION, HYGIENE, POOR, SUFFERINGS.

\section{INTRODUCTION}

The novel corona virus, COVID-19, which was first reported in Wuhan, China, has quickly spread across the world. India reported its first case on 30th January, 2020 in Kerala. Due to India being the second most populated country the number of COVD-19 cases grew rapidly. To restrict this exponential curve, the government initiated all India lockdown. India has confirmed over 97,03,914 cases as of 8th December, 2020, amongst which 91,78,269 have recovered already and 1,40,996 have been reported dead. Maharashtra alone adds up to around $20 \%$ of these cases. In these trying times, it is imperative to pause and analyze, to see what may be going wrong and what we could learn from the situation to make it better, and prevent further havoc. The situation of the world today

Biosc Biotech Res Comm P-ISSN: 0974-6455 E-ISSN: 2321-4007

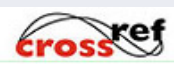

Identifiers and Pagination

Year: 2021 Vol: 14 No (6) Special Issue

Pages: $130-133$

This is an open access article under Creative

DOI: http://dx.doi.org/10.21786/bbrc/14.6.30
Commons License Attribn 4.0 Intl (CC-BY). compels all of us to stop and think, about what may have gone wrong and what lessons we can learn from the current situation to avoid such events in the future and to be better equipped to face similar events in case they are not preventable.

Millions and Billions of people during lockdown, quarantining, were not able to socialize, unable to meet one another, were not able to work efficiently, unable to attend school, college, gatherings, visit temples, travel and even lost access to public facilities like Gymnasiums, swimming pools and market areas. Places of recreation like cinemas and shopping malls were also shut and this made the people reflect on their dependence on the external world for fulfilment. Many found it difficult to cope with it and find satisfaction without external stimuli. This also led to an increase in people signing up channels available on the internet and television.

The whole world saw a setback due to the novel coronavirus and thus, it has made us all think about the need of the hour and the importance of being there for each other, while being away from each other. The best way to contribute in the current situation is by lending a ccepted after revision: $27^{\text {th }}$ May 2021

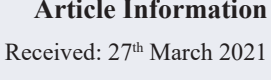


helping hand and not a shaking hand. The poor, homeless, jobless and migrant laborer are finding it extremely difficult to manage two square meals a day because their main source of income is daily wages, which has been compromised due to the current scenario.

Citizens around the globe are in restless and desperate state, struggling at home, in care centers, and hospitalsbattling the situation alone in their hours of need- which makes us value our loved ones. It has definitely taught us to rejoice what we have, while we have it and never take anything for granted. When all this is over, people will be thankful for the small pleasures of life like meeting a loved one, eating at a restaurant or something as simple as going to school and sharing the bench with a classmate. We are confronted with the true uncertainty of human existence and the utter vulnerability of human life. We have started valuing life a little too much. A single invisible virus can shake the whole world to its core to the extent that can cause it's closure- so never personify greatness. Something as little as it, has caused immeasurable damage to the society, physical health wise and mental health wise, both. It has caused a huge impact on the economies of various countries across the globe. All countries, rich and poor, are fighting alike. The virus does not differentiate between the rich and poor, black and white, homeless and people living in bungalows. We lack the basic sanitization skills, majority of us are so ignorant at it, that we actually only learnt the actual way of washing hands, during the pandemic.

\section{DISCUSSION}

The pandemic has revealed vast portion of greatness and kindness in our society. It has led to innumerable acts of selfless heroism weather be it in hospitals, care centers, helping poor, several centers distributing free food and also organizations helping stranded people to reach their homes. It has impelled many of us to use our greatest strengths to serve our greatest purposes, add more meaning to our life. Corona degraded not only the poor but also the rich who lost their jobs. This teaches us flexibility a man should always be ready for all kinds of job and never depend on one (Ling et al., 2020). The havoc that the virus create taught us that all we need to survive is food, no money spent could buy anything greater than food, So we should respect and value it. It also taught us that it's not a sole governments job to handle the nation but citizens too play a major part in creating awareness amongst themselves and help society as a whole. Given the situation People out of selfishness and carelessness- started listening, reacting and thinking about the safety of their fellow companions (Zhong et al., 2020).

This situation has shown us that we are all same regardless of our religion, culture, customs whether we are poor or rich. The virus simply does not choose. It connected us all in way, it showed us that we should all stick together. During this chaos, while many of us were panicking, it showed us the weight of humanity. It also teaches us that nature is superior to man and technology entering 21st century still we could not a permanent solution for a minute virus causing giant problems (Lee et al., 2020). We also need to learn that the first duty of the man or any government of to give priority to the basic needs of man. Everything else comes secondary There is a need for efficient management of distribution of food and other basic necessities. Medical institutions especially should be encouraged to provide free treatment to the ones in need first and then take care of everything else for everyone (Cruickshank et al., 2020).

We need to understand and work towards the motto of health is wealth and work towards the direction as it is not only the need of the hour but a goal for life Corona taught us that community needs each other -rich or poor can't thrive without each other. Anyone who lives with the notion that he doesn't need anyone is rearing nothing but false pride. This dependence of the community is not only limited to its needs but also the safety. As the social distancing, if not followed by the single person too can affect the entire group in an area. More than a basic safety measures, it also teaches us empathy towards society (Ehrlich et al., 2020). Social distancing has also lead to digital closeness, work efficiency has increased and not limited to the place of work which has increased flexibility of work hours and satisfaction too for many. People can carry out their work and perform at their own pace and multitask too. This is a good option for health too for those who want to avoid continuous sitting or other problems and increase health benefits too.

Not only the profession but the educational boundaries too increased and now acceptance to digital knowledge gained acceleration and students do not have to limit particular hours of teaching. Although this is beneficial from the teaching point of view, online exams still $r$ not efficient yet or rather we still don't have an efficient mechanism for conducting those and it requires a little more expertise (Marim et al., 2020). The virus has emphasized the need to monitor our immunity as it is necessary for not only this but all kinds of disease. Lockdown drew us to eat homemade food and mostly turned out to be a learning and healthy experience for all. It would be basic to say that we need a fit body to cope with everything and anything after this whole lot of traumatic deaths (Donnelly, 2020).

It also forced us to stress over the point that life is temporary as many unexpected death took place this year.We need to cherish company more, we need value a live person more and give him the gift of time how much ever possible as it is clear us now more than ever that we don't know what the next second will bring us. More than personal hygiene, environmental hygiene is neglected which has to be looked after for everyone's safety. The rising number of cases in the pandemic, means a rising amount of waste generated which needs proper care, handling and treatment. If there is carelessness and proper protocol of waste handling is not followed, it increases the risk in the exposed, and thus their chances of transmitting it further (Jayasena et al., 2020) 
In this pandemic, one very important lesson to be learnt is that of importance of maintaining a high level of immunity. It means preparing in advance for crisis, and not after the disaster strikes. This is shown by the better response that people with good immunity and fit lifestyles show to the virus in comparison to ones who are unhealthy. A daily incorporation of healthy habits like regular exercise and including fresh food items in place of preserved and junk items leads to a healthier body. Yoga is found highly effective to keep the mind and body happy and healthy(Andres Crespo et al., 2020). The virus has led to immeasurable damage to people in the form of financial, health and emotional losses. It has thus highlighted the Importance and need of creating security in the current global economy and also on an individual level (Aslan et al., 2020).

The widespread change that has occurred due to the pandemic, and its effects, such as lockdown has stressed the Importance of flexibility in life. The ones who work with an open mind and are accepting of change have been able to deal better with the situation than the ones who do not grow with change (Ratzan et al., 2020). The current situation, may be an indication, asking us to reflect and look back at our roots. The current lifestyle of people, includes living in metropolitan cities, travelling in crowded areas and being in public places. On the contrary, the rural life in our country, involves big verandas in the house with proper ventilation, and encourages open grounds and spaces. Rural living also involves healthy and fresh eating habits and less of processed foods which helps in maintaining the immunity at higher level (Cox, 2020).

The current global situation, along with its other lessons, also teaches us the Importance of being self-sufficient, as individuals, as a society and also as a country. We should make it a point to offer our support and help to local sellers, manufacturers, artists and merchants. This will go a long way in rebooting the economy and also help in providing more chances of earning a livelihood to our fellow brothers of the country (Berger and Reupert, 2020). In the past few months, with travel and tourism being on a standstill, many people have been unable to meet their families and friends. Some have been stranded in places far from home and unable to return to their hometowns. In this situation, we see the need of technology which has shown that distance can stop being a problem when you have a strong internet connection. People all over the globe have connected over the internet, using video calls, voice calls and other such available facilities which has made communication easier and more accessible to all. Thus, it highlights that technology advancement is imperative for the survival of mankind and to make it against odds (Pandey et al., 2020).

Also, during this lockdown we have seen a lot of people have been working from home. This means that many employees can exert flexibility in their work schedules and it also helps in cutting costs related to expenditure on rents and taxes of providing workspace. There is also a low absentee rate noted in situations where employees are allowed to work from home leading to higher efficiency of the system. This again is dependent on technology and good connectivity (Etteh et al., 2020)

The current scenario has brought to notice the importance of building a stable, affordable and accessible healthcare system. In times like these, it is a test of the efficiency of the current standing healthcare infrastructure and facilities, which, if fall short can lead to major compromise in the health status of the country (Khatib et al., 20200. One most important lesson to be learnt is one which reiterates the old concept of "prevention is better than cure" (Nanotkar et al., 2020; Nisargandha and Dadaraoparwe, 2020). It states that it is always better to prevent the emergence of a situation like this by adopting effective precautions (Sahu and Naqvi, 2020; Shah and Naqvi, 2020). Some of the related studies were reported (Gaidhane et al., 2020; Jachak et al., 2020; Joseph et al., 2020; Joshi et al., 2020; Lakhkar et al., 2020).

Interesting key issues on Covid-19 pandemic were addressed in studies of Acharya et al.(2020), Arora et al. (2020), Bawiskar et al. (2020), Bidkar et al. (2021) and Burhani et al.(2020). It involves the screening of travelers to contain the spread of diseases from one region to another. This virus, which was originally reported in Wuhan, has now spread to so many countries making it difficult to control. Thus, the control mechanisms should be as effective as the response mechanism to battle future events. From the global situation arising due to the coronavirus pandemic, much has been learnt and a lot more can still be learnt. Learning from the pandemic is going to be a continuous process which will require patience, insight and active participation by the individual, community and the country as a whole.

\section{CONCLUSION}

During this pandemic, the people have to make sure to take proper sanitary measures towards all physical contacts. With the knowledge being shared to all the population, people are getting aware of the situation as the lockdown slowly lifts. Even when the pandemic ends, may we keep with us the lessons it has taught us, and drift towards a safer, healthier and more conducive world for all.

\section{REFERENCES}

Acharya, S., Shukla, S. and Acharya, N., 2020. Gospels of a pandemic-A metaphysical commentary on the current COVID-19 crisis.

Arora, D., Sharma, M., Acharya, S., Shukla, S. and Acharya, N., 2020. India in "Flattening the Curve" of COVID-19 Pandemic-Triumphs and Challenges Thereof. Journal of Evolution of Medical and Dental Sciences, 9(43), pp.3252-3256.

Aslan, D. and Sayek, I., 2020. We need to rethink on medical education for pandemic preparedness: Lessons learnt from COVID-19. Balkan medical journal, 37(4), p.178.

Bawiskar, N., Andhale, A., Hulkoti, V., Acharya, S. 
and Shukla, S., 2020. Haematological Manifestations of Covid-19 and Emerging Immunohaematological Therapeutic Strategies. Journal of Evolution of Medical and Dental Sciences, 9(46), pp.3489-3495.

Berger, E. and Reupert, A., 2020. The COVID-19 pandemic in Australia: Lessons learnt. Psychological Trauma: Theory, Research, Practice, and Policy, 12(5), p.494.

Bidkar, V., Selvaraj, K., Mishra, M., Shete, V. and Sajjanar, A., 2021. A comparison of swab types on sample adequacy, suspects comfort and provider preference in COVID-19. American Journal of Otolaryngology, 42(2), p.102872.

Burhani, T.S. and Naqvi, W.M., 2020. Telehealth--A Boon in the Time of COVID 19 Outbreak. Journal of Evolution of Medical and Dental Sciences, 9(29), pp.2081-2085.

Cox, S., 2020. To dispense or not to dispense: Lessons to be learnt from ethical challenges faced by pharmacists in the COVID-19 pandemic. Developing world bioethics. Cruickshank, M. and Shaban, R.Z., 2020. COVID-19: Lessons to be learnt from a once-in-a-century global pandemic.

De Andres Crespo, M., Claireaux, H. and Handa, A.I., 2021. Medical students and COVID-19: lessons learnt from the 2020 pandemic. Postgraduate Medical Journal, 97(1146), pp.209-210.

Donnelly, S.C., 2020. COVID-19 and mental health: lessons to be learnt from the Fukushima disaster. QJM: Monthly Journal of the Association of Physicians, 113(11), pp.777-777.

Ehrlich, M.I. and Saif, M.W., 2020. Lessons Learnt from COVID-19: How Can We Prepare for Another Pandemic?. Archives of cancer biology and therapy, 1(1), p.22.

Etteh, C.C., Adoga, M.P. and Ogbaga, C.C., 2020. COVID19 response in Nigeria: Health system preparedness and lessons for future epidemics in Africa. Ethics, Medicine and Public Health, 15, p.100580.

Gaidhane, S., Khatib, N., Zahiruddin, Q.S., Gaidhane, A., Telrandhe, S. and Godhiwal, P., 2020. Depression, anxiety and stress among the general population in the time of COVID-19 lockdown: A cross-sectional study protocol. International Journal of Research in Pharmaceutical Sciences, 11(Special Issue 1).

Jachak, S., Phansopkar, P. and Naqvi, M.W., 2020. Impact of covid-19 in India, a disastrous pandemic outbreak. International Journal of Research in Pharmaceutical Sciences, 11(Special Issue 1).

Jayasena, H. and Chinthaka, W., 2020. COVID-19 and developing countries: lessons learnt from the Sri Lankan experience. Journal of the Royal Society of Medicine, 113(11), pp.464-465.

Joseph, M.B., Pohekar, S., Raut, A. and Patil, M., 2020. The palliative care and covid-19 pandemic. International Journal of Research in Pharmaceutical Sciences, 11(Special Issue 1).

Joshi, K., Acharya, N., Acharya, S., Joshi, S. 2020. A Grave Situation with COVID in the Gravid: A
Narrative Review. International Journal of Research in Pharmaceutical Sciences, 11 (1), pp. 496-99. https://doi. org/10.26452/ijrps.v11iSPL1.2837.

Khatib, M.N., Gaidhane, S., Khatib, M., Ahmed, M., Gaidhane, A. and Syed, Z.Q., 2020. SARS-CoV and SARS-CoV-2: Similar viruses with different trajectories. Wutan Huatan Jisuan Jishu, 16(5).

Lakhkar, B.B., Guru, B., Damke, S., Damke, S. 2020. Most Susceptible Duo in COVID-19 Crisis: A Literature Review. Perinatology ,21(3), pp. 112-23.

Latchoumi, T.P., Ezhilarasi, T.P. and Balamurugan, K., 2019. Bio-inspired weighed quantum particle swarm optimization and smooth support vector machine ensembles for identification of abnormalities in medical data. SN Applied Sciences, 1(10), pp.1-10.

Lee, V.J., Chiew, C.J. and Khong, W.X., 2020. Interrupting transmission of COVID-19: lessons from containment efforts in Singapore. Journal of travel medicine, 27(3), p.taaa039.

Ling, L., Joynt, G.M., Lipman, J., Constantin, J.M. and Joannes-Boyau, 0., 2020. COVID-19: a critical care perspective informed by lessons learnt from other viral epidemics. Anaesthesia, critical care \&t pain medicine, 39(2), p.163.

Marim, F., Karadogan, D., Eyuboglu, T.S., Emiralioglu, N., Gurkan, C.G., Toreyin, Z.N., Akyil, F.T., Yuksel, A., Arikan, H., Serifoglu, I. and Gursoy, T.R., 2020. Lessons learned so far from the pandemic: a review on pregnants and neonates with COVID-19. The Eurasian Journal of Medicine, 52(2), p.202.

Nanotkar, L., Dhanvij, S. and Joshi, A., 2020. COVID-19 and Importance of Social Distancing. Journal of Critical Reviews, 7(8), pp.1103-1104.

Nisargandha, M.A. and DadaraoParwe, S., 2020. Spread of coronavirus disease 2019 (COVID-19) during thelockdownintheIndianpopulationandpreventive measures. International Journal of Research in Pharmaceutical Sciences, 11, pp.328-332.

Pandey, S., Yadav, B., Pandey, A., Tripathi, T., Khawary, M., Kant, S. and Tripathi, D., 2020. Lessons from SARSCoV-2 Pandemic: Evolution, Disease Dynamics and Future. Biology, 9(6), p.141.

Ratzan, S.C., Sommarivac, S. and Rauh, L., 2020. Enhancing global health communication during a crisis: lessons from the COVID-19 pandemic.

Sahu, A. and Naqvi, W.M., 2020. Floating countries and corona pandemic: Impact of covid-19 on stranded cruise ships. International Journal of Research in Pharmaceutical Sciences, 11(Special Issue 1).

Shah, P. and Naqvi, W., 2020. Fighting and chasing the rogue virus-covid19. International Journal of Research in Pharmaceutical Sciences, 11(Special Issue 1).

Zhong, H., Wang, Y., Zhang, Z.L., Liu, Y.X., Le, K.J., Cui, M., Yu, Y.T., Gu, Z.C., Gao, Y. and Lin, H.W., 2020. Efficacy and safety of current therapeutic options for COVID-19-lessons to be learnt from SARS and MERS epidemic: A systematic review and meta-analysis. Pharmacological research, p.104872. 